ELORE (ISSN 1456-3010), vol. $12-1 / 2005$.

Julkaisija: Suomen Kansantietouden Tutkijain Seura ry.

Toimittaneet: Outi Fingerroos ja Kaarina Koski. Taitto: Jukka Talve.

[http://cc.joensuu.fi/ loristi/1_05/haa1_05.pdf]

\title{
VELISURMASTA SUVUN MUISTOKSI
}

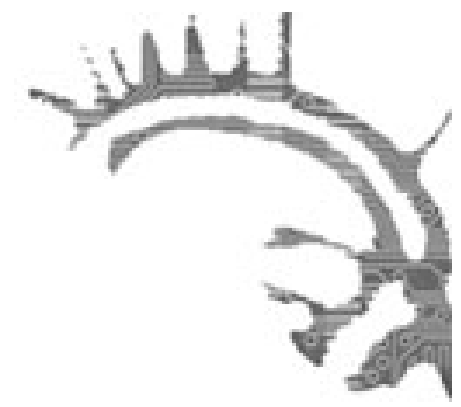

Riina Haanpää

Lähihistorian tapahtumien tarkasteluun liittyy aina outoa jännitettä, sillä parhaassa tapauksessa mukana kulkevat niin tutkijan kuin lukijankin omat tapahtumaan ja aikaan liittyvät muistot sekä mielikuvat. Kun tutkimus koskettaa vielä tutkijan omaa kulttuuria, omaa sukua ja perhettä, on tutkimukselle asetettu merkittävä haaste: "Mikä on tutkimuskohteen läheisyyden ja tutkijan oman roolin ja muistin merkitys?” Tässä artikkelissa kaivan esiin oman sukuni historian ja perinnön tarjoamia mahdollisuuksia tarkastelemalla suvussani tapahtunutta velisurmaa ja sen kerrontaa. Katsaukseni liittyy valtakunnallisessa Kulttuuristen tulkintojen tutkijakoulussa tekeillä olevaan jatkotutkimukseeni Jaskan ja Veikon henkirikokset - tutkimus kertomusten ja historiadokumenttien rakentamista henkilökuvista, jossa tarkastelen eteläpohjalaista yhteiskuntaa, kulttuuria ja mentaliteettia kahden, puukkojunkkareihin rinnastuvan rikollisen elämänvaiheiden ja heistä kertovien kertomusten kautta.

Isoisäni veli Veikko puukotti Kauhajoella vuonna 1974 humalapäissään veljensä Väinön kuoliaaksi. Tapahtumaa on suvussamme käsitelty eri tavoin, ja se on epätavallisuutensa (1) vuoksi noussut myös kerronnan kohteeksi, jonka kautta paljastuu monia asioita suvustamme ja suvun jäsenten välisistä suhteista. Lähemmän analyysin kohteeksi olen valinnut syyskesällä vuonna 2001 tekemäni kolmen sukulaisnaisen, Ruutin, Saaran ja Leean, haastattelut (2). Haastateltavista Ruut on veljesten sisar, Saara heidän serkkunsa ja Leea heidän veljentyttärensä. Haastattelut poimin käyttäen kriteereinä muun muassa niiden tallennusajankohtien läheisyyttä, jolloin voisin ainakin olettaa päämäärieni saavutettavan tiedon suhteen olleen kaikissa haastatteluissa yhteneväiset. Tarkastelen näiden haastattelukertomusten kautta Väinön tappoa sekä suhtautumista siihen:'Miten tapahtunut on suvussa ymmärretty?" ja "Mitä se on suvulle merkinnyt?" Tarkastelen myös sitä, miten tähän kuolemaan suhtauduttiin yhteisön ja eteläpohjalaisen kulttuurin sisällä.

Koska tapahtunut tappo oli sukummekin sisällä epätavalliseksi koettu kuolema, on mielenkiintoista herättää keskustelua poikkenkesellisista kuolemista - tämän Eloren teeman puitteissa. Poiminkin haastattelukertomuksista esiin tulevia näkökulmia ja suhteutan niitä muiden poikkeuksellisista kuolemista kertovien tutkimusten esittelemiin näkökulmiin. Pohdin mahdollisia eroja Outi Fingerroosin (2004) 


\section{Rina HaAnPÄÄ}

käsittelemien poikkeavien kuolemien, etenkin vuoden 1918 sodan punaisten kuolemien, sekä Juha Pentikäisen (1990) kuvaamien kansanuskossa ja kirkkolaissa esiin tulevien poikkeuksellisten kuolemien välillä: "Millä perusteilla ja miten kuolemat määritellään näissä eri aineistoissa poikkeuksellisiksi?” ja "Miten tarkastelemani velisurma niihin suhteutuu?"

Kun tässä tutkimuksessa tarkastellaan historiallista tapahtumaa ja siitä kertovia haastattelukertomuksia, on paikallaan pohtia hieman myös lähdekriittisiä kysymyksiä. Historiallisista dokumenttilähteistä käytän katsauksessani ainoastaan lopullista Korkeimman Oikeuden päätöstaltiointia liitteineen (3). Oikeudenkäyntien ja poliisikuulustelujen pöytäkirjojen lähdearvoa rikollisuuden tutkimuksessa on usein kyseenalaistettu, vaikka ne päälähteiksi historiallisissa rikollisuuden tutkimuksissa mielletäänkin. Niiden todistusarvoa heikentävät tekijät on jaettu todistajien havaintojen epätarkkuuteen, lausuntojen epäluotettavuuteen sekä itse lausunnonantotilanteessa ja ylöskirjaamisessa tapahtuneisiin mahdollisiin vääristymiin. Pöytäkirjojen onkin katsottu ilmentävän voimakkaammin oman aikansa kulttuurisia sekä valtakäytäntöjen rakenteita kuin niitä ilmiöitä, jotka liittyvät käsiteltyihin juttuihin. (Rajala 2004, 44.) Keskeistä näissä lähdekriittisissä pohdinnoissa näyttää olleen luotettavan sekä faktanomaisen tiedon saavuttamisen tavoite ja siihen vaikuttavien heikentävien tekijöiden tiedostaminen sekä analysointi. Mutta kysymyksen oikeudenpöytäkirjojen ja todistajanlausuntojen annista voisi siis sijoittaa myös toisaalle, niiden kykyyn kertoa tapahtumia ympäröivästä todellisuudesta (Ginzburg 1996, 156-164; Portelli 1991, 241-269). Enemmän kuin todisteita ovat todistajanlausunnot niiden antajien näkemyksiä tapahtumista. Näin myös tuomiokirjojen todistajanlausunnoissa korostuisi muistamiseen ja kertomiseen liittyvät prosessit sekä merkitykset.

Kysymystä haastatteluaineistoni muodostumisesta sietää myös pohtia. Tutkimuskohteen ollessa oma yhteisö ja suku nousevat kulttuurin sisäisen näkökulman edut sekä haitat esiin. Kenttätyötä käsittelevässä kirjallisuudessa on paljon pohdittu edellä mainittuja teemoja sekä tutkijan roolia silloin, kun hän tekee tutkimusta omassa yhteisössään. Puhutaan tutkijan persoonasta työkaluna, ulkopuolisen perspektiivin hallinnan vaatimuksesta, uudenlaisten kysymysten esittämisestä, "mitään ei saa ottaa annettuna" -asenteen välttämättömyydestä (Suojanen 1997, 149-157). Pihla Vuorinen on myös kirjoittanut niistä hyödyistä ja ongelmista, joita tutkimuskohteen ja tutkittavien läheisyys mahdollisesti antaa tai aiheuttaa. Hyödyiksi voidaan laskea tutkijan jakamat yhteiset kokemukset tutkittavien kanssa, joiden ansiosta tutkija tietää, mitä kannattaa kysyä. Läheisten tutkiminen vaatii myös subjektiivista ja emotionaalista ymmärrystä, ja tällainen suhde tutkittaviin nähdään tutkimusta hedelmällistävänä ja rikastuttavana piirteenä. Ongelmakohtina Vuorinen taas näkee tutkijan ja perheenjäsenen roolin sekoittumisen: tutkija on yhtä aikaa sisä- ja ulkoryhmäläinen. Myös läheisyyden vaikutuksen eksplikoiminen saattaa olla ongelmallista. (Vuorinen 2002, 348-363.)

Edellä mainitun kaltaiset huomiot ovat kohdistuneet lähes yksinomaan kentällä olon ja aineistonkeruutilanteiden käytäntöihin. Sen sijaan vähemmälle on jäänyt omaa kulttuuriaan ja sukuaan tarkastelevan tutkijan kriittisen otteen analy- 


\section{VELISURMASTA SUVUN MUISTOKSI}

sointi, tai se, millä tavalla tietoinen tutkija on tarkastelemastaan asiasta. Omaa sukuaan tutkivalta vaaditaan omanlaistaan tapaa lähestyä tutkimuskohdetta. Itse esimerkiksi olen haastattelutilanteissa ensisijaisesti ollut sukuni jäsen - viisaan maine ei tilanteissa rasita - ja sellaisena myös haastateltavat ovat minua kohdelleet. Olen kyennyt olemaan samaa mieltä haastateltavien kanssa itse haastattelutilanteissa, ja tarpeen tullen olemme pystyneet neuvottelemaan yhdessä tapahtumien kulusta, kumpikin omiin muistoihimme tai kuulemiimme kertomuksiin nojautuen. Esimerkiksi omakohtaiset muistoni setäni puukotuksesta 1970-luvun lopulta ovat olleet mielenkiintoisia keskustelun aiheita haastattelutilanteissa. Muistojani tuosta tilanteesta hallitsevat mielikuvat, jossa setäni tulee sisään tupaan (isovanhempieni taloon) verinen paita päällä. Hän juo vettä napolla ämpäristä ja kääntyy sen jälkeen isäni puoleen tokaisten: "[] aaha Jaska, lähäreks viemähäm mua Seinäjoelle?"

Tämän edellä kuvatun muiston voisi tietysti tulkita jopa keksityksi, enkä minäkään enää voi erottaa, onko edellä kuvaamani tapahtunut juuri noin vai ei. Tapahtunut tuntuu kuitenkin todelta suhteutettuna ensinnäkin sukulaisteni taipumuksiin joutua väkivaltatilanteisiin (ks. viite 1). Toisekseen tuo muisto on minulle hyvin todellinen, koska todennäköisesti olen kehittänyt sen suvussa kuulemieni kertomusten kautta, ajatuksissani ja jopa nostalgiassani. Mutta tärkein tehtävä tuolla muistolla on siinä, että se kiinnittää myös minut omakohtaisine kokemuksineni osaksi suvun historiaa. Olen tavallaan suvun jäsenenä ja vastaavaa kokeneena tasaarvoinen keskustelemaan ja jakamaan mielipiteitä. Osaan myös kysyä sopivista tappoaihetta koskevista sekä sivuavista seikoista jo olemassa olevien ennak-kotietojeni avulla. Haastatteluissa on aina tavalla tai toisella sivuttu myös omia kertomuksiani veljeksistä:

RH: Ne oli kovia tappelemaan Vänö ja Veikko, et ne yhdes aina toisiaan. Tai ei ne keskenään, vaan sitten jos nüitten päälle byökättiin. Et kerrankin oli joku, joku oli josai tuol Kaubajoen kylillä, nïn oli Vä̈nön päälle byökänny, nïn Veikkoo oli menny ja listiny sitte.

Saara: Juu-u, niin ei, tottahan se sellaanen oli. (Saara, 2001.)

Minulla on jo ennen haastattelutilannetta ollut jonkinasteinen tieto siitä, mitä mieltä kyseinen haastateltava on tapahtumasta, siksi usein taposta on erilaisissa tilanteissa puhuttu. Olen siis tapahtumien rinnalla kasvamisen ja suvun arvoihin kiintymisen ansiosta kyennyt ymmärtämään tapahtunutta haastateltavien kannalta. Tämä seikka onkin mahdollistanut haastattelutilanteissa syntyneen varsin perinpohjaisen tapahtumien käsittelyn. Pystyn myös suvun ja sen elinpiiriin kuuluvana jäsenenä kuvaamaan tapahtuman sosiaalista ympäristöä tavalla, josta historialähteet eivät kerro. Olen siis omaksunut suvun perinteen, sen kansanomaisen historian kompetenssin edellisiltä sukupolvilta, ja hallussani on tietoa siitä, miten pitää toimia. Jorma Kalelan sanoin "[kansanomainen historia] on historiaa, joka tavallaan 'tarttuu' vaatteisiin" (2000, 38).

Mutta ongelmia syntyy - ja syntyy myös ambivalenssi suhtautuminen, kun mieli muuttuu haastattelukertomuksen ollessa tarkasteluni alla. Haastattelutilanteen 


\section{RiIna HaANPäÄ}

sujuessa keskinäisen, yhteisymmärryksellisen keskustelun merkeissä - tai niin tilanne ainakin sillä hetkellä koetaan - on itse tulkinnan tekeminen jo hankalampaa. Miten tulisi varautua oman tutkittavan yhteisön reaktioihin? Odotetaanko minulta tutkijana sittenkin toisenlaista ymmärrystä, toisenlaista totuutta tai peräti jonkun tahon mielipiteen vahvistamista? Helena Ruotsala $(1998,101)$ on myös pohtinut oman kulttuurin tutkimusta ja päätynyt samankaltaisiin ongelmiin: omasta kulttuurista tulevan tutkijan oletetaan usein saavuttavan uuden totuuden. Ratkaisuksi kyseiseen ongelmaan tarjotaan kuitenkin tutkijan oman osuuden ja mahdollisen oman kulttuurisen sokeuden problematisointia. Yksi keino on myös antaa mielipiteiltään vaihtelevan, laajan ja monipuolisen muistitietoaineiston puhua puolestaan.

Kun tarkastelussani keskityn muisteltuun tapahtumaan, niin pyrin ensisijaisesti tavoittamaan sekä tulkitsemaan muistelijoiden omia kokemuksia ja tulkintoja. Muistelupuheelle on kerronnan lajina tyypillistä, että se muodostuu menneen mieleen palauttamisesta ja tarpeen tullen myös selittämisestä. Muistelija tuottaa muistellessaan aktiivisesti menneisyyttään ja historiaa. Menneisyyttään muisteleville ihmisille omat muistot ovat aina totta sekä kokemuksellisesti että psykologisesti. Muistelijan pyrkimyksenä on tulkinnan lisäksi myös ymmärtää ja hallita omaa menneisyyttään eli tavallaan tulla tietoiseksi omasta historiastaan. Motiivina muisteluun voi olla myös tarve selvittää itselle tai muille, miksi menneisyys on ollut juuri tietynlaista. (Ukkonen 2000, 86, 237-238; Peltonen 1996, 282.) Käsittelen muisteltuja kertomuksia taposta osana muistitietohistoriaa (Oral History), joka siis tuo esiin sen, minkälaisia asioita ihmiset pitävät muistelemisen arvoisina ja miten he niitä muistelevat, eli mikä on niiden merkitys. Muistitieto kertookin enemmän merkityksistä kuin itse tapahtumista. (Ukkonen 2000, 30-31, 37; Portelli 1997, 22, 50; Portelli 2002, 67-69.) Esimerkiksi tarkastelemalla oman sukuni kertomuksia taposta voin samalla analysoida, minkälainen on kertojien oma merkityksellinen historia. Voin myös tehdä päätelmiä niistä suvun kulttuurisista käsityksistä ja tulkinnoista, jotka pitävät Veikon ja Väinön muistoa yllä.

Muistitietoaineisto edellyttää uutta lähdekriittistä näkökulmaa. Muistitietoa ei voida arvioida perinteisen, ensisijaisesti luotettavuutta painottavan lähdekritiikin valossa, sillä monet tekijät vaikuttavat muisteluaineiston muotoutumiseen: muistitiedon subjektiivisuus sekä sen tulkinnallinen luonne, puhumattakaan nykyisyyden vaikutuksesta tehtyihin tulkintoihin. Näitä vaikutuksia ei pidetä muistitietotutkimuksessa varsinaisina ongelmina. Sen sijaan, että muistitietoa arvotettaisiin sen tarjoamien tietojen luotettavuuden tai paikkansapitävyyden perusteella, puhutaan muistitietoaineistojen tarjoamasta bedelmällisestä tiedosta (Kalela 2000, 90-91; Kalela 1999, 139-154; Ukkonen 2000, 86-88). Tällöin lähteiden arvottamisen perusta ei olisi enää luotettavuus vaan (niiden välittämä) informatiivisuus. Ennen kaikkea juuri muistitiedon subjektiivinen luonne avaa uusia mahdollisuuksia tulkita siitä nousevia merkityksiä ja se tekee muistitietoaineistosta myös mielenkiintoisen tutkimuskohteen.

Muistelua voidaan siis tutkia paitsi menneisyyden tulkintana niin myös sosiaalisena toimintana sekä vuorovaikutustapahtumana. Muistitietoa tuotetaan usein haastatteluin, joten aineiston analysoinnissa arvioidaan tutkimuskohteiden 
kanssa käydyn muistelun vuorovaikutuksellista suhdetta ja oman historian tuottamisprosessin luonnetta. Analysoinnissa voidaan pohtia myös sitä, miksi asioita ja tapahtumia muistetaan juuri tietyllä tavalla: pohditaan esimerkiksi arkaluontoisten tai suorastaan häpeällisiksi koettujen tapahtumien "väärin muistamisen" kulttuurisia syitä sekä merkityksiä. (Ukkonen 2000, 86, 95-97.) Kertojilla on aina omat syynsä unohtaa, muuttaa tai parannella menneisyyttään nykyhetken ja oman ajattelun edun mukaisiksi (vrt. Peltonen 2003, 13). Miksei siis myös oman suvun tutkijalla olisi tällaisia - lojaliteetinkin vuoksi syntyneitä - haluja muodostaa oma näkemys suvun menneisyydestä? Tutkittaessa itseään koskevaa menneisyyttä, varsinkin kun kyse on arkaluontoisista tapahtumista, on valintoja tehtävä sekä suhteessa itseen että tutkittaviin. On päätettävä, mitä minä haluan suvustani kertoa tarkastelemieni haastattelukertomusten kautta sekä minkä päätelmiin vaikuttavan näkökulman kautta sukuani kuvaan. Tutkimus onkin tavallaan eräänlaista jatkuvaa neuvottelua itseni ja tutkimusaineiston välillä. Missään nimessä tutkija ei kykene tulkinnoissaan tuottamaan objektiivista suhtautumista ja jäsentelyä omaa sukuaan kohtaan.

Kysymys siitä, miten voi eettisesti kestävästi kirjoittaa rikollisista, vaatii jatkuvaa pohdintaa (4). Myös aika asettaa rajoituksia lähihistoriassa tapahtuneiden rikosten tutkimiselle: mikä määrittää, milloin tutkimuksen kohteena olevan rikollisen ja yksilön kuolemasta on kulunut riittävästi aikaa, jotta häntä voidaan käsitellä historiaan kuuluvana "kertomuksena" muiden joukossa. Tutkijalla on velvollisuuksia sekä tutkittavia että mahdollisia lukijoita kohtaan, ja ylipäätään eettisten periaatteiden on kosketettava koko tutkimusta, ei vain haastateltavien suojaamista. Näin ollen haastattelukertomuksien tärkein merkitys onkin siinä tiedossa, jonka ne minulle antavat taposta kertomisen, poikkeukselliseen kuolemaan suhtautumisen, ihmisen, yhteisön ja kulttuurin vuorovaikutussuhteesta. Ja kun halutaan esitellä mennyttä aikaa, historiaa ja sen ihmisiä, saavutetaan päämäärä monin verroin paremmin kunnioittamalla heidän yksilöllisyyttään ja näyttämällä heidät tutkijan rakentamina mahdollisina ja uskottavina, mutta ei ainoina oikeina tulkintoina (ks. Davis 2001, 8).

\section{PoikKeuksellinen KuOlema}

Kysymystä siitä, mikä on poikkeuksellinen kuolema, siis normaalin kuoleman vastakohdaksi mielletty kuolema, on muun muassa uskontotieteilijä Outi Fingerroos tarkastellut väitöskirjassaan Haudatut muistot (2004). Fingerroos on siirtokarjalaisten muistelun kautta tutkinut rituaalistetun kuoleman merkitysten rakentumista sekä sitä, millaisia merkityksiä muistitiedosta on mahdollista löytää ja tavoittaa. Normaali kuolema saa osakseen oikein suoritetun kuolemanrituaalin, joka on arvokas ja julkinen ja jolla on merkitystä sekä eläville että toimen kohteena olevalle kuolijalle. Kuollut saa vainajan statuksen ja yhteisöllisten rituaalien kautta tunnustetun arvon kunniallisena vainajana. Tästä lähtökohdasta käsin Fingerroos $(2004,252)$ rakentaa 


\section{RiIna HaAnPää}

laajemman merkitystason tulkinnan kuolemanrituaaleille. Hänen tulkintansa keskittyy pääasiassa poikkeuksellisten kuolemien, lapsen kuoleman, itsemurhan tehneiden ja varsinkin sota-ajan kuolemien, tarkasteluun. Erityisesti huomio kiinnittyy yhteen kategoriaan, vuoden 1918 sodan vaiettuihin punaisiin kuolemiin, joita käsitellessä erilaiset kuoleman rituaalistamiseen liittyvät mallit joutuvat näiden pahojen äkkikuolemien kontekstissa kokonaan toisenlaiseen valoon: Punaisten kuolemien julkisuusarvo oli poikkeava, ne ritualisoitiin poikkeuksellisesti, samaten kuolemien yhteisöllinen käsitteellistäminen ja jälkeenpäin tapahtuva muisteleminen on ollut poikkeavaa.

Kuolemanrituaalien keskeisimpänä funktiona Fingerroos pitää niiden yhteisöllistä jaettavuutta ja julkisuutta. Tilanne on kuitenkin toisenlainen, kun kuoleman arvo ja julkisuus kyseenalaistetaan. Tällöin puhutaan poikkeuksellisista kuolemista erotuksena normaaleille kuolemille ja kuolemanrituaaleille. Poikkeavat rituaalit ovat siis seurausta poikkeavista tavoista kuolla. Esimerkiksi äärimmilleen vietyinä kuolemanrituaalit ovat kokonaan kiellettyjä, häpeällisiä ja jopa muistelussa salattuja. Tällaisia häpeällisiä, pahoja, ei-toivottuja sekä ei-julkisia kuolemia ovat muun muassa itsemurhan tehneiden kuolemat, joista vaietaan ja ne suljetaankin pois yhteisöllisen julkisuuden piiristä. Vaiettujen kuolemien piiriin kuuluvat myös vuoden 1918 sodan punaisten kuolemat. Lasten kuolemat taas ovat Fingerroosin kategoriassa ei-toivottuja mutta normaaleja kuolemia, joiden arvo ja kunnia toki tunnustetaan. Mutta lapsen kuoleman hautajaisrituaali ei useinkaan ole yhteisölle avoin eikä se toteuta normaalin kaavan mukaista rituaalia. (Fingerroos 2004, passim, 249, 255-257.)

Kuolleelle kuuluva arvo kyseenalaistuu varsinkin, kun on kyse pahoista ja bäpeällisistä kuolemista. Fingerroos (2004, 257, 263-269) puhuukin vuoden 1918 sodan kuolemia käsitellessään vaikenemisen ilmapiiristä. Tällä hän tarkoittaa poikkeuksellisen sota-ajan luomia kieltoja, jotka koskettavat paitsi poikkeuksellisten kuolemien yhteyteen kuuluvien julkisten rituaalien kieltämistä niin myös niitä käsittelevien muistojen kieltoa ja hiljaisuutta. Raskaita omakohtaisia menetyksiä kokeneet eivät tapahtumista jälkeenpäin puhuneet, niistä ei ollut helppo kertoa eikä niistä edes saanut kertoa. Julkisen muistamisen lupa koski vain sodan voittaneiden valkoisia sankarikuolemia, ei hävinneiden punaisten teloituskuolemia eikä joukkohautoja. Vaikenemisen pakko olikin ylhäältä päin säädeltyä, ja näistä punaisten poikkeuksellisista kuolemista muodostui yhteiskunnallisen vallankäytön kohde. Virallisen muistamisen kiellot näkyivät niin historian julkisissa esityksissä kuin henkilökohtaisissa muistoissakin, koska kiellot pakottivat yhteisön reagoimaan joko vaikenemalla tai kehittämällä omaa perheen tai pienyhteisön perinnettä (vrt. Peltonen 1996). Vasta 1960-luvulla tapahtunut käänne antoi sodan hävinneelle puolelle mahdollisuuden julkiseen muistamiseen.

Myös Juha Pentikäinen on tutkimuksessaan Suomalaisen lähtö tarkastellut poikkeuksellisia kuolemia, muun muassa statuksettomia vainajia, itsemurhan tehneitä sekä lapsen kuolemaa. Pentikäisen mukaan ylipäätään yllättäen tapahtunut kuolema, joko tapaturmainen tai yhtäkkinen sairastuminen, koettiin poikkeukselliseksi ja myös rituaaliset käytänteet olivat sen mukaisesti poikkeavia. Kuolemanriitit oli- 


\section{VELISURMASTA SUVUN MUISTOKSI}

vat minimaalisia tai ne jäivät kokonaan suorittamatta. (Pentikäinen 1990, 62, 88.) Esimerkiksi kirkollinen laki määritteli vielä 1800-luvulla poikkeuksellisten kuolemien hautaustoimitukset jaettavaksi hiljaisiin, paheellisiin ja häpeällisiin hautauksiin. Hiljaisen hautauksen osakseen saivat muun muassa viinaan kuolleet ja äkkipikaisuudessa itsensä tappaneet. Paheellinen hautaus oli äkkipikaisuudessa toistensa tappaneiden sekä vankeudessa kuolleiden ja murhattujen lasten osana. Ja häpeällinen hautaus taas toimitettiin tietoisesti itsemurhan tehneille sekä teloitetuille. (Pentikäinen 1990, 126-127.)

Kirkon harjoittaman erottelukäytännön on katsottu heijastuneen myös kansanperinteeseen. Eritoten vainajat, joiden aseman kirkko näki ongelmallisena, esiintyivät myös kansanuskossa niin sanottuina sijattomina vainajina. (Pentikäinen 1990, 127; Pohjola-Vilkuna 1995, 113-133.) Varsinkin surmatut lapset sekä murhatut kuuluivat sijattomien sielujen piiriin. Kun kuoleman tuli olla julkista ja kollektiivista saavuttaakseen hyväksyttävän arvon, aiheuttivat murhan kohteeksi joutuneet päänvaivaa. Pahan kuoleman kohtaamiselle ei ollut järjestäytyneitä muotoja, ei myöskään yllättävän kuoleman, esimerkiksi tapon seurauksena kuolleen kohtaamiselle. Näitä kuolemia ei voitu työstää rituaalein, eivätkä ne näin kansanuskon käsitysten mukaan saavuttaneet normaalin kuoleman symbolista asemaa. Sijattomiksi vainajiksi laskettiin myös rikoksen tehneet, esimerkiksi lapsenmurhaajat, pahantekijät, varkaat, murhaajat ja itsemurhaajat. Nämä vainajat olivat kansanuskon mukaan sijattomia, kummittelemassa rangaistukseksi teoistaan. Julkisen rangaistuksen vastaavat vainajat saivat myös paheellisen hautauksen merkeissä, jolloin heitä ei haudattu siunattuun multaan vaan laskettiin ilman kristillisiä toimituksia kirkon kiviaidan ulkopuolella sijaitsevaan hautaan. (Pentikäinen 1990, 127-129.)

Poikkeuksellisiksi käsitettävien kuolemien yhteydessä normaalista poikkeavat käytänteet toimivat erottavina tekijöinä. Tämä näkemys poikkeuksellisista kuolemista perustuukin riittikäsityksiin, joiden mukaan kuoleman sosiaalinen haltuunotto myytein ja riitein osoittaa kuoleman merkityksen (esim. Anttonen 1999, 11; Fingerroos 2004; Pentikäinen 1990). Fingerroosin erittelemät poikkeukselliset kuolemat nousevat ajallisesti maailmansotien väliin sijoittuvasta muistitiedosta käsin. Tarkastelun kohteena ovat olleet niin kaupunki- kuin maaseutukonteksti ja niiden yhteisöjen tuottamat tulkinnat kuolemanrituaaleista. Pentikäisen tulkinnat poikkeuksellisista kuolemista nojaavat taas pitkälti 1800-luvun kirkkolain piiriin sekä sen heijastuksista kansanuskon kontekstiin. Nämä tutkimukselliset keskustelut poikkeuksellisista kuolemista käsittelevät siis lähinnä näiden kuolemien rituaalisia merkityksiä. Myös huomioni haastattelukertomuksissa esiin tuleviin Veikon ja Väinön poikkeuksellisiin kuolemiin kiinnittyy niin ollen niihin liittyneisiin rituaaleihin tai niiden puuttumisiin.

\section{Etelä-Pohjanmaa}

Väkivallantekijän stereotyypiksi kuvataan usein mainetta ja kunniaa uroteoilla tavoitteleva puukkojunkkari. Etelä-Pohjanmaalla ja väkivallalla onkin historialliset 


\section{RiInA HaANPäÄ}

juurensa. Väkivallan ja rikollisuuden aste oli Etelä-Pohjanmaalla 1800-luvulta alkaen korkea, muuhun Suomeen verrattuna aivan omaa luokkaansa. Väkivallan esiintymiseen on etsitty monia syitä. Muiden muassa puukon käytön yleistyminen ja hillitön viinankäyttö, joka sai hullut "hupsoittelemahan", ovat tarjonneet selitysmalleja väkivaltaisuuksien ilmenemiselle (Virrankoski 1965, 182-190). Sakari Pälsin varovaisen arvioinnin mukaan puukolle karttuisi ehkä isku päivää kohti ja juhlapäiviksi kaksi, ja suurimmaksi osaksi iskut antoi alkoholin vaikutuksen alainen, ihmisihon "veistelyyn" tottunut puukkosankari (Pälsi 1955, 64, 75). Kustaa Vilkuna taas näkee maakunnassa vietetyt rahahäät viinatarjoiluineen syypäinä korkeille tappotilastoille, sillä häät eivät olleet pohjalaiset häät, ellei niissä edes yhtä miestä tapettu tai pahasti puukotettu (Vilkuna 1949, 131-135). Viina ja puukko näyttävätkin olleen lähes erottamaton pari. Juovuspäissä käytiin verisimmät tappelut, ja varsinkin häätapot kuuluivat parhaisiin urotöihin.

Heikki Ylikangas on puukkojunkkaritutkimuksiensa selitysmalleissa tarkastellut väkivaltaa suosivaa eteläpohjalaista arvomaailmaa. Ylikangas toteaakin maakunnan poikkeavan rikollisuuden sekä väkivallan ilmiön syntyneen ennemmin taloudellisten, sosiaalisten ja ympäristötekijöiden rakenteiden muutoksen myötä kuin vain puukon käytön ja alkoholin kulutuksen lisääntymisestä. Rikokset olivat nuorten miesten ja nimenomaan alemman sosiaaliluokan edustajien vapaa-ajan harrastus. Yhtenä merkittävimpänä rikollisuutta säätelevänä tekijänä voidaankin pitää alenevaa säätykiertoa ja sitä kautta taloudellisen tilanteen muuttumista. (Ylikangas 1976, 253-269.) Suurten perhekokojen vuoksi osa nuorista joutui hankkimaan elantonsa muualta kuin kotitilalta päätyen yleensä muille tiloille palkollisiksi, ja näin heidän yhteiskunnallinen statuksensa laski. Lisäksi tervanpolton väheneminen, joka oli ennen tarjonnut runsaasti työtä ja sivuelinkeinon maakunnassa, kärjisti varallisuuserot äärimmilleen. Kun vielä yhteiskuntajärjestelmä korosti itsenäistä yritteliäisyyttä ja henkilökohtaisia pätevyydennäyttöjä, oli epäonnistuminen sosiaalisessa arvoasteikon nousussa omiaan nostattamaan protestihenkeä (Ylikangas 1976, 255). Protestin ilmaisemisen ainoana keinona pidettiin normeista piittaamatonta käytöstä, jolloin ansioita rakennettiin rikoksien avulla.

Kertomukset puukkojunkkariajan rikollisista sekä heidän teoistaan nostavat puolestaan paljon syvemmällä vaikuttavat kulttuuriset tekijät esiin. Se, mitä ja miten puukkojunkkareista kerrotaan, kertoo siis myös eteläpohjalaisesta kulttuurista. Väkivallasta ja rikollisista kertovissa kertomuksissa on havaittavissa puukkojunkkaritradition sekä populaarikulttuurin vaikutusta. Aikaisemmat ja perinteessä tunnetuimmat kertomukset Isontalon Antista ja Rannanjärvestä sekä Pukkilan Jaskasta ovat osa haastattelemieni kertojien kulttuurista kompetenssia. Kulttuurista kompetenssia ilmaisee ennen kaikkea tietämys makkunnan perinteestä: "[Pukkilan Jaska] se on ollu niiren kaveria sen Ison-Antin ja Rannanjärven, niin, niin, mutta siitä Antista mää oon sellaasta kuullu, että se teki sosiaalista työtä (Saara 2001).” Myös virallinen, julkinen representaatio puukkojunkkareista erilaisine kaupallisine ja kirjallisine tuotteineen (esimerkiksi Santeri Alkion teos Puukkojunkkaritvuodelta 1894) on epäilemättä muovannut kuvaa rikollisista ja siten myös puukkojunkkareille annettuja merkityksiä. Tuo kuva eteläpohjalaisista häjyistä saa vielä nykyään- 


\section{VELISURMASTA SUVUN MUISTOKSI}

kin kahtalaisia tunteita osakseen. Yhtäältä heidän muistoaan hävetään ja kavahdetaan, toisaalla häjyistä ollaan ylpeitä ja heidät on valjastettu jopa markkinavoimien käyttöön mainostamaan maakunnan omaa identiteettiä ja kulttuuria (Ylikangas 1974, 10). Ylipäätään Etelä-Pohjanmaa on nähty puukkojunkkarien maakuntana ja populaarikulttuuri on vielä inspiroitunut tästä imagosta. Veikon tekemästä taposta kertomiselle saattaisikin löytyä juuret juuri tästä perinteestä.

Pohjalaisuudella on siis ollut oma merkityksensä suomalaisten maakuntaja heimoluonteiden kuvauksissa, ja ne ovat toimineet myös oivina, joskin stereotyyppisinä selitysmalleina. Pohjalaiset tunnetaankin sekä pahassa että hyvässä. Muun muassa pohjalaista mieskoodia luonnehtii Juhani Sipilä, joka on tarkastellut Antti Tuurin Pobjanmaa-proosasarjassa ilmenevää alueellista ja kansallista identiteettiä. Sipilä toteaa, että "heimostereotypioihin liittyy nimenomaan tietoinen performatiivinen aspekti: pohjalaisen pitää esittää hurjaa luontoaan, ettei asia pääse itseltä ja muilta unohtumaan” $(2002,176)$. Mutta luonteen äärimmäisyyksien piirteitä esitetään myös "hyvässä valossa". Jo mainitut, pahimmillaan puukkojunkkari-ilmiön syntyyn johtaneet työteliäisyyden, itsenäisen yritteliäisyyden ja toiminnan sekä sitä kautta menestymisen arvot nähdään pohjalaisuuden parhaina puolina. Kustaa Vilkuna $(1969,170)$ on myös nimennyt Etelä-Pohjanmaan omaleimaiseksi maakunnaksi, sen "uljaat rakennukset, oma kieli, korkeatasoinen kansantaide [..] kaikkea tätä hallitsi omaleimainen eteläpohjalainen luonne". Omaleimaisuus syntyi Vilkunan mukaan voimakkaasta vanhojen maakunnassa vallinneiden paikallisihanteiden noudattamisesta, "etusijan sai mies, joka oli rohkea, käskevä, voimakas, varakas, isosanainen mies [..] joka ei pelännyt, mutta joka yllytti. Hän oli nuorten ja naisten ihanne”. Myös eteläpohjalaisessa, etenkin heitä itseään koskevassa huumorissa näyttäisi tahtominen ja toiminnallisuus ominaisuuksina korostuvan (Knuuttila 1994, 8691). Pohjalaisuuteen sisältyisikin siis kunnian, komeuden, miehisyyden ja voiman kulttuuriset piirteet. Ilmaistaanko ja ylläpidetäänkö näitä heimopiirteitä sitten suvussamme taposta kerrottaessa ja nähdäänkö Veikko tai Väinö eteläpohjalaisina miehinä? Vai onko tämä historiallinen, sosiaalinen ja kulttuurinen pohjalaisuuskategoria kykenevä muuttumaan?

\section{TAPPO}

Suurimmaksi syyksi veljesten välisiin kohtalokkaisiin kiistoihin on maanviljelysyhteiskunnissa nähty kilpailu perheen rajallisesta omaisuudesta, etenkin maaomaisuudesta. Keskinäiset konfliktit ovat olleet erityisen ankaria, jopa velisurmiksi äityneitä, varsinkin jakamattomina pidettyjen maatilojen perijöiden kesken. Esimerkiksi Anu Koskivirran tarkastelemasta 1700-luvun lopun Itä-Suomen henkirikollisuudesta löytyy veljeskilpailulle ja henkirikoksille vastaavuuksia. Kiistojen yleisyys saa selityksensä ensinnäkin väestöllisistä paineista ja toisekseen veljesten keskinäisistä vuorovaikutuksen ja vastuunjaon määristä. Velisurmia tapahtuikin pääasiassa talouksissa, joista puuttui voimakas, kiistoja välittävä patriarkka. (Koski- 


\section{RiInA HaANPäÄ}

virta 2002, 283-288.) Myös sataviisikymmentä vuotta myöhemmin, tarkalleen vuonna 1974 tapahtuneessa tapossa nousevat samat velisurmien motiivit esiin. Korkeimman Oikeuden päätöstaltioinnista käy ilmi eri todistajien arvelut ja tiedot siitä, että elokuvakoneenkäyttäjä Veikolla (1932-1977) oli ollut riitaa veljensä, maanviljelijä ja sekatyömies Väinön (1927-1974) kanssa heidän kotitilansa lunastamisesta: "J]a [Veikko] oli jo aikaisemmin uhannut surmata Väinön, oli useita kertoja ilmoittanut tälle, että koska Väinö kuitenkin kuolee kahden ja puolen vuoden kuluttua, niin on sama, vaikka tämä kuolee ennemminkin.” (KO, nro 1105/559.)

Veljekset asuttivat tapahtuman aikoihin vielä jakamatonta kotitilaa kaksistaan, Veikko poikamiehenä ja Väinö varhain leskeksi jääneenä. Väinön lapset olivat kuitenkin jo muuttaneet pois tilalta. Muut siskot ja veljet olivat kukin tahoillaan perustaneet omat maatilat tai kodit lähiseudulle. Mutta yhteyttä sisarusten ja varsinkin veljesten välillä pidettiin, vallankin kun varsinaisen kotitilan hoidosta vielä yhdessä vastuu kannettiin. Ennen tapahtunutta tappoa olivat sukulaisten välit siis olleet normaalit ja hyvät. Mutta tapon jälkeisissä oikeudenkäynneissä ilmeni jo kahtiajakautuneisuutta mielipiteissä Veikosta, Väinöstä ja suhteista naapureihin ja sukulaisiin. Osa sisaruksista ei osannut kertoa oikeastaan mitään epäedullista veljesten väleistä, sillä "ainakin niillä kerroilla, jolloin oli veljiensä luona käynyt, oli kuulusteltava saanut sen käsityksen, että nämä sopivat keskenään pois tiehensä”. Myöskään kotitilan lunastuksesta aiheutuneiden veljesten välisten riitojen synnystä eivät kaikki sukulaiset olleet samaa mieltä, mahdollisia lunastajia kun oli muitakin kuin vain kaksi veljestä. Osan mielestä taas veljesten välit olivat jo aiemmin, ennen tilakaupan keskusteluja, olleet tulehtuneet, ja Veikolta oli monesti jouduttu ottamaan aseet pois: "[K]yläläistenkin kuulusteltava tietää Veikkoa pelänneen ja pelko on ollut niin suurta, että kyläläiset ovat lukinneet ovensa, kun ovat tienneet Veikon olevan ryyppyreissulla.” (KO, nro 1105/559.)

Tappoa edeltäneet tapahtumat käynnistyivät kuitenkin jo edellisenä iltana, jolloin miesseurue veljeksineen oli aloittanut alkoholin nauttimisen. Seuraavana päivänä lähdettiin yhdessä hankkimaan lisää alkoholia.

Matkalla Veikeko oli eräästä talosta saanut kissanpennun ja ottanut sen mu-
kaansa seurueen käytössä olleeseen henkilöautoon. Autossa Vä̈nö oli vastustellut
kissan ottamista mukaan ja ehdottanut, että kissa jätettäisiin autosta pois, mistä
sunttuneena Veikko oli ilmoittanut, että jos kissa kuolee, kuolee Vä̈nökin. Seu-
rueen palattua takaisin veljesten asunnolle ja jatkettua siellä alkobolin nauttimis-
ta Veikeko oli todennut mukanaan tuomansa kissan kadonneen. Tästä sunttu-
neena ja syyttäen seurueen muita jäseniä kissansa tappamisesta Veik.ko oli otta-
nutpöydällä olleen punkon. (KO, nro 1105/559.)

Haastateltavani Ruut, veljesten sisar, kertoo puukotukseen johtaneista tapahtumista sekä sen syistä seuraavasti:

Ne oli hakenu Hyypästä vïnaa ja juonehet ja sittek. kissanpoijaat se oli tuonu se Veikeko sieltä, ja ei se ollu nähänys sitä [kissaa], nïn se oli ruvennu, Veskua 


\section{VELISURMASTA SUVUN MUISTOKSI}

sitte bäristelehen veittellä jotta, että se on sen tappanu, että hän tappaa sun, kun sä oot bänen kissansa tappanuj ja, se mitääk kissaa ollu tappanu, kissa oli johonakis sängyn alla, ni, se, niin kuinka se, sitte makas sängys silti sitte, kuinka se sen veitten kaans sänkyhym meni, surittahan niin se siinä oli sitä [Väinöä] tökkiny. (Ruut 2001.)

Veikko, kuten koko seurue, oli tilanteessa ollut alkoholin vaikutuksen alaisena. Myös Veikon sairastama sokeritauti todennäköisesti osaksi edesauttoi lopputulosta. Päätöstaltiointiin liitetyn lääkärintodistuksen mukaan Veikko oli ollut"jonkinlaisessa bämärätilassa, jolloin hän on käyttäytynyt väkivaltaisesti” (KO, nro 1105/559). Kuitenkin itse tappo näyttää olleen puhdas vahinko. Väinö oli rauhoitellut veljeään tämän saatua raivonpuuskan ja käyttäydyttyä uhkaavasti muita seurueen jäseniä kohtaan. Ja yrittäessään estää Veikon lyöntiaikeet olikin Väinö itse saanut vatsaan ja rintaan puukonpistoja, jotka aiheuttivat kuoleman lähes välittömästi. Korkein Oikeus jatkaa vielä tapahtumien selvitystä:

Edelleen kiblakunnan oikeeus on lausunut selvitetyksi, että Veikeko oli ubannut
bäntä edellä kerrottujen tapabtumien jälkeen pidättämään tulleita kabta poliisi-
miestä seisomalla rakennukesen portailla punkko kädessäja ilmoittamalla lyövänsä
punkolla jokaista sisälle pyrkivääa. (KO, nro 1105/559.)

Haastateltavistani Leea, veljentytär, joka oli tapahtuman aikaan vielä lapsi, selvittää Veikon olotilaa veljensä puukotuksen jälkeen: 'Niin kun huhupuheet kuuluu sanovan, jotta se on ollu, niin kun että silimät on ollu aivav väärip päin, että mustuaasia ei oo näkyny yhtään, että niin ni, se on ollu ihan semmoses, pois tolaltaansa (Leea 2001).”

Teostaan Veikko sai lopulta vankeutta kuusi vuotta ja kuusi kuukautta. Korkein Oikeus määritteli tapon tahalliseksi, sillä oikeuden mukaan Veikon oli täytynyt käsittää, että hänen useat lyöntinsä saattoivat aiheuttaa Väinön kuoleman. Lisäksi häneltä takavarikoitiin rikoksen tekovälineenä käytetty puukko, joka julistettiin valtiolle menetetyksi. (KO, nro 1105/559.) Veikko kuoli vuonna 1977 vankilassa ollessaan vain pari kuukautta ennen ehdonalaiseen pääsyään. Rikos sïs määriteltiin Korkeimman Oikeuden toimesta tahalliseksi tapoksi, eikä muita lain suomia mahdollisuuksia tapahtuman käsittelyyn ole olemassa. Mutta tämän lain tulkinnan sekä selvitysten lisäksi on kuitenkin puukotuksesta ja siihen johtaneista syistä kertova, lähinnä sukulaisten ylläpitämä muistitieto. Tätä muistitietoa tulkitsemalla saadaan esiin ne mielipiteet, kokemukset ja tunteet, joita tapaus aikoinaan ihmisissä herätti.

\section{Muisteltu KuOlema}

Molempien veljesten olemuksista tai luonteenpiirteistä haastateltavillani on runsaasti luonnehdintoja. Eritoten kuvauksissa korostuvat positiivisiksi koetut omi- 


\section{RiInA HaANPäÄ}

naisuudet ja persoonallisuuden hyvät puolet niin Veikolla kuin Väinölläkin. Kerronnassa toistuvaa ovat moninaiset kertomukset molempien veljesten työteliäisyydestä, hyvyydestä, komeasta ulkonäöstä sekä eteläpohjalaisille niin ominaisesta ja merkittävästä reiluudesta. Esimerkiksi Leea luonnehtii Veikkoa seuraavasti: "Veikko oli sittet taas ittestäänsä et se oli semmonen kauhian hyväntuulinen iloonen semmonen, et se oli iloonen ja lapsirakas ja eläinrakas oikeen." Veikon ja Väinön keskinäisiä välejä kuvataan milloin hyviksi ja milloin taas ei niin hyviksi. Esimerkiksi veljesten kotitalon naapurissa asuneen Saaran mukaan "jollakinlailla siin oli kyllä siinä jotakih häihäräppiä sitte”. Mutta ylipäätään veljesten suhteessa ei ongelmia nähty: "[Se] oli mielestäni rehti mies, ei niillä ollum mitään, muuta makasivat (sunnuntaisin) kumpikin seljuul toises sängys toinen toises sängys toinen, ne oli komeita miehiä molemmat nuorena (Ruut 2001).” Negatiivisiksi ominaisuuksiksi kertojat luokittelevat lähinnä molempien veljesten ajoittain runsaan alkoholin käytön, ja tämä myös antaa mahdollisuuksia tapahtuneen ja sen syiden tulkinnalle. Saara ei kokenut Veikkoa pelkästään mukavaksi mieheksi: "Ja] Veikko, kun se tuli pöhönään, se oli ikävä’. Väinö taas oli Leean mukaan pirullinen juovuksis, että oikeen sellaanen ärsyttävä.” Näyttääkin siltä, että se seikka, kumpi veljeksistä kulloinkin mielletään toista pahemmaksi, riippuu kertojasta ja hänen ottamastaan kannasta tapahtuneeseen. Kertojat muun muassa arvioivat tietämiänsä muiden sukulaisten mielipiteisiin johtaneita syitä, esimerkiksi Saara kerronnassaan mieltää veljesten sisaren olevan avoimesti Veikon puolella, "se ei tuominnus sitä Veikkoa, sillälailla pystyny tuomittemahan, kun se oli sen rakas pikkuveli". Mielipiteen valinta tapahtumasta kertomiseen riippuu siis siitä, kuka puhuu ja mistä näkökulmasta. Anne Heimo on todennut samankaltaisen päätelmän tarkastellessaan Sammatin vuoden 1918 muistitietoa. Se, miten ja millaisia kertomuksia sodasta kerrotaan, riippuu siitä, kerrotaanko sodan punaisesta vai valkoisesta näkökulmasta. Eri motiivit korostuvat ja tiettyjä asioita jätetään kertomatta molemmin puolin. (Heimo 2000, 7; Peltonen 1996, 2003.) Punaiset ovat säilyttäneet oman versionsa siitä huolimatta, että virallinen Suomi tuomitsi toisin. Ja toisaalta ylemmältä taholta tulleen muistelemisen kiellon vuoksi joutuivat perheet ja yhteisöt jopa kehittämään omat yksityiset muistamisen muodot (esim. Fingerroos 2004, 257; Peltonen 1996). Myös kysymys siitä, kuka kysyy, on olennainen. Pihla Vuorinen (2001, 129-130) on tutkinut perhekerrontaa, jokapäiväisen jutustelun ja muistelun lomassa kerrottavia juttuja suvun jäsenten tekemisistä ja sanomisista. Vuorisen mukaan etenkin negatiivisia muistoja on vaikeampi kertoa perheen ulkopuolisille jäsenille. Juuri kuulumiseni sukuun onkin saanut suvun eri jäsenet ilmaisemaan eriävät mielipiteensä veljeksistä, ja jonkinlaista linjanvetoa on haastateltavien kertomuksista havaittavissa.

Vaikka tätä erimielisyyden tulkintaa kerrotuista veljesten kuvailuista pystyykin tavoittamaan, ovat kuitenkin vakuuttelut kaikkia suvun jäseniä yhdistävistä hyvistä väleistä ominaista kertojille: "Meil ei ikänä, minkäämmoista sanaharkkaa ollu”, (Ruut 2001), eikä myöskään Saaran mukaan "ikänä näiren kans riirelly eikä ollu minkäämmoista riitaa näiren kaans”. Käsitykset suvun hyvästä ilmapiiristä etenkin ennen tarkasteltua tapahtumaa jaetaankin juuri sukulojaalisuuden perusteella. Mutta tapahtuman jälkeen tämä tietynlainen lojaliteetti loppui. Väinön lapsien tie- 


\section{VELISURMASTA SUVUN MUISTOKSI}

dettiin - jo oikeudenkäyntien perusteella - kantavan kaunaa Veikkoa kohtaan teon jälkeen, "tottahan ne varmahan kantoo kaunaa ja vihas Veikkua yli kaiken, ilimam muuta se on ihan selevä juttu" (Leea 2001). Väinön läheiset vaativat myös Veikolle lain suomaa ankarinta mahdollista rangaistusta, kun taas veljesten sisarukset tyytyivät kannanotoissaan syyttäjän esittämään rangaistusvaateeseen (KO, nro 1105/559). Tapahtuneen johdosta suvun keskinäinen yhteydenpito vähenikin vuosien ajaksi, kunnes vähitellen palautui lähes aikaisemman kaltaiseksi (esim. Ruut 2001; Leea 2001).

Perheen ja suvun ristiriitaista suhtautumista Veikkoon ja myös Väinöön lisäsivät osaltaan oikeudenkäynnissä esiin tulleet erimielisyydet tuomion laadusta, mutta myös ympäröivän kyläyhteisön mielipide.

Ibmiset ei olsi byväksynys sitä, ei kukaa ei byväksyny tuota tekua, se oli sellaanek katto sellaanen oikeuteenkin tuli tällaanen, kun oikeutehem mentibin, nïn kerättibin nimiä, jotta sitäa (Veik.koa) ei saa enää tännep päästää. Se oli sellaanen kuule sellaanen kaubujuttu täs kylällä, jotta sitä olis pelijänny varmahan jos se olis ollu vapaalla sen jälekehen. (Saara 2001.)

Vankilasta tuli kyselyjä nïn, jotta oliko se sitten niin kun järjellänsä vai kuinka, minä sittev vastasin ettem mä ainakaa nïn, nähänyk koskaan sohisevan. Veera (veljesten sisko) oli sanonu että ehorottomasti sen pitää vangita elämän ijäksensä. (Ruut 2001.)

Se oli vain semmoonen traakinen tapabtuma sïnä kyläs, ja kyllähän sitä tietysti ajateltibin että mitäs sittek kun Veikeko tulee linnasta pois ja tämmöstä, että varmahan eli sittes sellaanen peleko niillä, itte kullaki. Isä (veljesten veli) orotti sitä Veikon vapautumista kotia ja sellaasta. (Leea 2001.)

Kumpikin osapuoli, sekä sukulaisten suhtautumiset että kyläläisten mielipide, kuvaavat herkästi toista pahaksi tai toisten reaktiota tapahtumaan negatiivisesti koettavaksi. Kysymys siitä, pitäisikö Veikko ja hänen tekonsa kokonaisuudessaan kieltää vai ei, näyttäisi lankeavan suuren yleisön eli kyläyhteisön asennoitumisesta johtuvaksi. Tämä ei näytä tarjoavan positiivista mielipiteen mallia sukulaisille, mutta ei myöskään yleisen mielipiteen valta vaikuta kaikkiin sukulaisten käsityksiin. Suvun - tai sen osan - mielipiteen muokkautumista kylän yhteisen mielipiteen mukaan näyttäisi siis tapahtuneen. Kuitenkin on nyt erotettava haastateltavien mielipiteiden kohteet: Itse teko, tappo, nähtiin kielteisenä ja yleisesti ottaen tappaja tuomittiin suvun ja myös kyläyhteisön kesken. Mutta haastateltavien mielipiteet Veikosta ihmisenä ja persoonana sekä suvun jäsenenä eivät olleet välttämättä tapon jälkeenkään kielteisiä.

Sekä Fingerroosin kuvaamien että Pentikäisen esittelemien, kansanuskossa ja kirkkolaissa esiin tulleiden poikkeuksellisten kuolemien kategorioiden välillä on eroja suhteessa tähän tappotapaukseen. Kummassakin tapauksessa julkisen rituaalin ja muistelun epääminen kiistävät vainajan arvon. Mutta tarkastelemassani 


\section{RiInA HaANPäÄ}

velisurmassa suku ja kyläyhteisö tuomitsivat vain tappajan. Eli tappo ei tässä tapauksessa leimannutkaan pahaksi uhria ja hänen muistoaan, kuten Pentikäisen esittelemässä vanhassa kansanuskossa oli tapana tuomita murhan ja tapon uhrit sijattomiksi vainajiksi. Tekijä tuomittiin yksinomaan aiheuttamansa poikkeuksellisen kuoleman kautta.

Huomioitavaa tässä poikkeuksellisen kuoleman käsittelyssä on myös se, että poikkeuksellinen ei suinkaan ole synonyymi pahalle tai pelättävälle kuolemalle. Poikkeava kuolintapa ei välttämättä muuta ihmisen arvoa tai tee suoritettavista rituaaleista poikkeavia. (Fingerroos 2004, 262-263.) Väinön kuoleman puukotuksen uhrina voisi luokitella poikkeukselliseksi kuolintavaksi ja ehkä myös Pentikäistä mukaillen pahaksi kuolemaksi. Mutta pahaksi mielletyksi kuolemaksi se konkretisoituu vasta (ja vain) teon tekijään eli Veikkoon liitetyn kerronnan kautta. Sen sijaan tapetun Väinön kuolema julkistettiin, muun muassa ensin taposta ja sen osapuolista kertovilla lehtiartikkeleilla, sitten lehdessä julkaistulla kuolinilmoituksella ja viimein normaalien ja julkisten hautajaisten vietolla. Leea kertoo veljesten hautajaisista muistamaansa:

Sittek ketä niit on ollu sittes silloon Väinön hautajaisis, nuita vanhempia mukuloota, et ei mulla ei oo siitä oikiastaansa sellaasta mielikuvaa, että niin niin, eikä Veikon hautajaasista sen kummempia. (Leea 2001.)

Veikko sen sijaan eristettiin suvun piiristä. Vähäistä yhteyttä vankilaan pidettiin kirjein ja joulukortein (tekijän hallussa kirjeitä), mutta Veikkoa ei enää entisellä tavalla mielletty osaksi perhettään ja sosiaalista yhteisöään. Veikko itsekin kirjoittaa vankilasta lähettämässään kirjeessä, että "kun olen nyt semmoisella mustalla listalla, että ei kukaan oikein halua muistaa eikä tuntea" (3.3.1975). Kokiessaan itsensä yhteisönsä ja sukunsa jäseneksi oli toisten tuomiolla Veikolle suuri merkitys. Tämänkaltaista sosiaalista kuolemaa (Fingerroos 2004, 262-263; Bronfen \& Webster Goodwind 1993, 6-9) ei kuitenkaan voi rinnastaa fyysiseen kuolemaan, sillä sosiaaliseen kuolemaan liitetään ruumiiseen kohdistuvia arvottavia käsityksiä sekä yhteisöllisiä vallankäytön muotoja. Esimerkiksi vanki voi olla sosiaalisesti kuollut, sillä hänet on vankilaan tuomittuna erotettu sosiaalisista siteistään yhteisöön. Kyse ei siis tällöin ole kulttuurisista arvotuksista tai kuolemanrituaalein suoritettavista erilleen asettamisista vaan epävirallisesta, tietynlaisesta sosiaalista kontrollista, jota suku sekä kyläyhteisö Veikkoa kohtaan harjoittivat. Tällä kontrollilla ja "yhteydenpidon asteella" oli selvä yhteys siihen, mitä Veikkoa ja hänen tekemäänsä velisurmaa kohtaan tunnettiin: Osalle, lähinnä Väinön läheisille, Veikko oli paha, kuollut ja unohdettu. Osalle hän edelleen oli olemassa osana sukua ja hänen vankilasta vapautumistaan odotettiin.

Veikon kuoleman vankilassa arvellaan olleen itsemurhan: "[K] un sitä epäiltihij jotaki [kyläyhteisö], jotta se ois ittensä joinki, jos se ajatteli sitä, jotta hän ei enää pysty elämähän kunnollista elämää (Saara 2001).” Kertojan mukaan Veikko pelkäsikin vapautumistaan vankilasta ja siksi päätyi itsemurhaan. Ulla-Maija Peltonen on väitöskirjassaan tutkinut muun muassa vuoden 1918 sotaan liittyviä punai- 
sen puolen uskomustarinoita, joissa ilmenee voimakkaana vanhan uskomusperinteen vaikutus. Punaiset kehittelivät omat tarinansa teloittajien myöhemmistä vaiheista, ja niissä kerrotaankin, kuka teki itsemurhan, kuka sairastui, kuka päätyi alkoholistiksi. Näissä tarinoissa punaisten oikeudenmukaisuus-käsityksen mukaan kohtalo rankaisi teloittajia, koska laki ei sitä tehnyt. (Peltonen 1996, 223.) Peltosen tulkintaa soveltaen voisi olettaa myös Veikon kokeneen kyläläisten käsityksen mukaisen rangaistuksen. Tekemällä itsemurhan Veikko olisi saanut tuomion, vaikka hän siis kärsi myös lain määräämän rangaistuksen. Joka tapauksessa Veikon hautajaisista muodostui hiljaiset, vaatimattomat sekä ei-julkiset, koska hänen kuolemansa ei hänen tekojensa vuoksi ansainnut julkista ja normaalia rituaalia. Fingerroosin $(2004,413)$ mukaan hiljaisia hautajaisia pidetäänkin merkkinä poikkeuksellisesta kuolemasta. Mutta hautajaiset kuitenkin pidettiin ja kuoleman arvo tunnustettiin. Veikon kuolemaa ei silti merkitty kuolinilmoituksella lehteen eikä julkista kutsua esitetty. Hautajaisten muotoon vaikuttivat ennen kaikkea sukulaisten henkilökohtaiset tunteet yleisten käytänteiden sijaan. Veikko kuoli vankilassa sairauden murtamana, joten hänen kuolemansa voidaan tulkita poikkeukselliseksi kuolinpaikan vuoksi. Mutta varsinaisesti poikkeukselliseksi kuolema koetaan Veikon tekemän velisurman myötä. Tämän teon kautta Veikko on oikeutettu moraaliseen arvioon, jossa paha saa palkkansa.

Vuoden 1918 sodan punaisen puolen vainajilta kiellettiin kuoleman normaalit rituaaliset käytänteet sekä heidän muistonsa arvo. Tämä konkretisoitui vaikenemisen pakossa, jota säädeltiin yhteiskunnan tasolta ylhäältä päin. (Fingerroos 2004, 268-269.) Sen sijaan Veikon kuolemasta ei virallisen vallan taholta käskien vaiettu, eikä sitä sen kummemmin määritelty. Mutta kyläyhteisö asetti kuitenkin kielteisellä suhtautumisellaan epävirallista kontrollia Veikon kuoleman muistamista kohtaan: tavallaan siis yksilöt päättivät, mitä yhteisö sääti.

\section{"EI SANKARIAINESTA, EI KUNNIAA EI MAINETTA"}

Väinön kuolema veljensä tappamana oli tietysti ei-toivottu sekä poikkeuksellinen kuolema. Mutta rituaalisessa mielessä se ei ollut poikkeava kuolema, vaan Väinön kuolema sai osakseen arvon sekä normaalit hautajaiset. Veikon kuolemaa voisi taas rituaalisessa mielessä pitää poikkeavana, sillä hänen hautajaisensa olivat vaatimattomat sekä hiljaiset. Mutta ennen kaikkea se, mikä aineistossani määrittää Väinön ja Veikon kuolemat poikkeaviksi, on tappo, siis itse teko ja sen tuomittavuus.

Fingerroosin tulkinnat poikkeuksellisista kuolemista, joiden arvo ja julkisuus perustuivat rituaalistettuihin vallankäyttöihin, sopivatkin osin tutkimusaineistooni. Väinön kuolemaa voisikin verrata ei-toivottuun, mutta kuitenkin normaalin kuoleman kategoriaan erotuksena vaietuista sekä häpeällisistä kuolemien kategoriasta. Tällaisen yllättävän kuoleman eli tapon kohtaamiseen ei kuitenkaan ollut järjestäytyneitä muotoja, koska käsitykset elämästä ja sen jatkuvuudesta yhtäkkisesti järkkyivät. Sen sijaan Pentikäisen esittelemien 1800-luvun kirkkolain käsittämien 


\section{RiInA HaANPäÄ}

poikkeuksellisten kuolemien sekä etenkin sijattomien sielujen folkloreen tutkimusaineistoni kuolemat istuvat huonosti. Kirkkolain paheellisen hautauksen päivät ilman kirkollisia rituaaleja ovat ohi, mutta toki tiettyä mallia ne ovat tarjonneet poikkeuksellisen kuoleman kohdanneen hiljaisten, ei-julkisten hautajaisten viettoon. Sijattomien sielujen folklore, joka on olennainen osa vanhakantaista vainajauskomusta, ei pahan ja häpeällisen kuoleman kategorioillaan sovi enää tutkimaani velisurmaan. Häpeä asettuu velisurmassa toisaalle, tapon tekijään, eikä

enää laisinkaan uhriin. Ja tappajan häpeäkin on ennen kaikkea hänen teossaan ja sen jälkiseurauksissa.

Häpeä on tässä velisurmassa keskeinen käsite, ja se on vaikuttanut myös kerrontaan. Suku on suhtautumisessaan osin mukautunut ympäristöönsä ja omaksunut teon tekijän tuomitsevan linjan. Tiiviissä kyläyhteisössä toisten asioihin on tunnettu luonnollisesti mielenkiintoa, joko myötämielistä tai sitten pahansuopaa. Yhteisöissä vaadittiin norminmukaista käyttäytymistä, ja sitä myös tavalla tai toisella kontrolloitiin. Veikko joutui tapon vuoksi häpeään niin virallisen kuin kyläyhteisönkin harjoittaman epävirallisen kontrollin kautta; kyläyhteisön käyttämät keinot ulottuivat moraalisesta paheksunnasta aina Veikon takaisin paluun vastustamiseen. (Epävirallisesta kontrollista ks. Ylikangas 1976, 305-309; Rajala 2004, 26-27; häpeän käsitteestä ks. Siltala 1994, 13-16; Veikon takaisinpaluun vastustamisesta ks. edellä Saara 2001.) Tappo siis sekoitti kyläyhteisön järjestystä ja arkea. Tappo myös teki julkiseksi niin uhrin kuoleman kuin tappajan häpeänkin, mutta myös suvun surun. Velisurmassa suru sekä häpeä olivatkin yksinomaan suvun sisällä, sillä ulkopuolisiin ei syitä voinut sysätä. Tapahtuneen julkisuus taas mahdollisti kyläyhteisön kollektiivisen suremisen, mutta myös kollektiivisen tappajan tuomitsemisen.

Mutta mitä ja miten tästä tapahtumasta ja sen seurauksena poikkeuksellisesta kuolemasta kerrotaan? Suvun kerronta on pääasiassa keskittynyt Veikkoon, hänen ominaisuuksiensa ja piirteidensä kuvaamiseen. Kukin kertoja kertoo Veikosta eri tavoin, oman mielensä mukaan. He ovat kokeneet tapahtuman eri tavoin, jopa samankin suvun sisällä, ja he kertovat juuri sen, mitä heidän nähdäkseen tapahtui. Kyse onkin Seppo Knuuttilan mukaan kerrottuna muuttuvasta menneisyydestä, tuotetusta todellisuudesta (1994, 23, 60-61). Menneisyyden tapahtumien merkitykset siis muuntelevat eri kertojilla ja näistä erilaisista suhtautumisten variaatioista avautuu mahdollisuus Veikosta kertomisen merkityksen purkamiseen. Tulkinta Veikosta näyttäisi vaihtelevan siirryttäessä yksilöstä ja tarkemmin sukupolvesta toiseen. Sukulaisten reaktiot ja asenteet Veikkoon ovat erilaisia riippuen siitä, kuinka läheiseen yhteyteen he kuuluivat. Esimerkiksi Ruutille ja Saaralle, jotka edustavat samaa sukupolvea Veikon ja Väinön kanssa, omien kokemusten ja suhtautumisen jäsentämisessä keskeistä on tapahtuman selvittäminen ja siitä kertomisen sekä tulkinnan kautta selviytyminen. Molemmat haluavat antaa lausuntonsa - vuosikymmeniä tapahtuman jälkeen - niihin käsityksiin, joita esimerkiksi kyläyhteisö lietsoi. Saara ja Ruut nostavat kumpikin esiin Veikon omaamat toisenlaiset arvot: rehtiyden ja työnteon, eivätkä negatiiviset puolet, kuten tappelijanominaisuudet välttämättä paljon kerronnassa korostuneet. Naiset ovat siis merkityksellistäneet muistot 


\section{VELISURMASTA SUVUN MUISTOKSI}

Veikosta juuri taposta kertomisen kautta, mutta kertominen on mahdollistanut myös hyvien muistojen esiin nostamisen. Veikosta onkin kerronnan kautta muodostunut aktiivinen toimija, sen sijaan että hänestä olisi tehty ainoastaan ongelma.

Toista ja nuorempaa sukupolvea edustavan Leean tulkinnoissa eteläpohjalaisuuden vaikutukset heijastuvat jo selvemmin. Leean kerronnassa huomio kiinnittyy tapon lisäksi veljesten muihin ominaisuuksiin. Heistä on esimerkiksi tehty kovia mutta reiluja pohjalaisia tappelijoita, joita voitiin ihailla, "tottahan ne varmahan sellaasia pelekäämättömiä oli, mutta ei ne erellä mitää”. Vaikka Veikko säilyy ensisijaisesti tappajana Leean muistoissa, on hänestä toisenlaisiakin, rillumarei-tyypin ja elämästä nauttijan muistoja: "Veikko oli semmoonen vissihin että, huoletoon että, vähä semmoonen ronski, että saa sanua että tili tuli tili meni, kiersi tua ympäri maailmaa ja pitäjää." (Leea 2001.) Juuri "ronski rillumarei" - tapa kertoa eteläpohjalaisittain ja laskea leikkiä Veikon ominaisuuksilla - löytää juurensa historiallisen puukkojunkkariuden ja erittäinkin miehisen perinteen mallien parista. EteläPohjanmaalla on näyttänyt juuri tällaisten tappeluaiheiden käsittely tarjonneen mielenkiintoa kertojille, sekä miehille että naisille. Väkivalta on ollut eräs menneitten aikojen tunnusmerkki, ja aiheiden taustalla heijastuukin pohjalaisen puukkojunkkariuden arvomaailma, miehuuden, komeuden ja näkyvän omankädenoikeuden heroistinen traditio. (Siikala 1984, 209, 221.)

Taposta kertomisen tarkastelu osoittaa muistitiedosta esiin nousevan merkityksen tärkeyden. Saaran ja Ruutin kertomuksissa muistot todentavat Veikon ja velisurman olleen jotain aivan muuta kuin pohjalaisia puukkojunkkari-stereotypioita toistavaa kerrontaa. Se on ollut käsittämätön murhenäytelmä, josta selviytyminen on vaatinut alkuun myös suvun kahtiajakautumisen. Ja varsinkin, kun kyläyhteisö leimasi Veikon vaaralliseksi ja epätoivotuksi yksilöksi, on selviytymiseen ja yhteisössä edelleen elämiseen tarvittu suvulta luonnetta. Tappo yksittäisenä raakana väkivallantekona ehkä provosoi esiin ne aiemmin piilossa olleet antipatiat tai vastaavasti sympatiat, joita kyläyhteisö Veikkoa ja miksei koko sukuakin kohtaan tunsi (vrt. Nygård 2001,145). Voisikin siis todeta, että taposta kertomisen perinne on toiminut paremmin kuin siitä vaikenemisen perinne. Kertomisella on selkeästi ollut eheyttävä vaikutus. Sen kautta on pystytty selittämään tapahtuman syyt ja seuraukset, muun muassa suvun jakautuneet mielipiteet. Tapahtuneesta on myös selkeästi haluttu välittää muisto jälkipolville, eikä sitä suinkaan ole salailtu: ’[K]yllä siitä on ollu puhetta, että mä oon pojillekis siitä sanonu (Leea 2001).” Mielenkiintoista on myös, että kertomalla taposta seuraaville kuunteleville sukupolville on siihen vähitellen kiinnittynyt myös pohjalaisia puukkojunkkarikertomusten piirteitä.

Pauliina Latvala on tarkastellut Suvun suuri kertomus kirjassaan samannimisen keruuhankkeen aineistoa, joka sisältää perheen ja suvun välittämää historiakerrontaa pääosin itsenäisyyden ajan Suomesta. Suvussa tapahtuneesta taposta kertominen ei teemana sinällään suhteudu Latvalan esiin nostamiin suvun suuren kertomuksen tematiikkoihin. Mutta hän on toisaalla todennut olennaista olevan se, mitkä teemat ovat suvussa arvostettuja, eli löytyykö suvusta kertomisen aihetta (Latvala 2000, 4). Siksi siis kysymys siitä, miksi Veikon tekemästä velisurmasta suvussamme kerrotaan, on merkittävä. Yhtenä suvusta kertomisen motivaationa 


\section{RiInA HaANPäÄ}

voi olla oman elämän arvottaminen (Latvala 2000, 4). Mutta esimerkiksi varsinaiseksi suvun sankaritarinaksi, jollaisilla pyritään saamaan kunnioitusta omille "juurille”, ei tapahtunutta tappoa äkkiseltään kuitenkaan mieltäisi. Keskeistä kerronnassa näyttäisikin olevan kyky selviytyä, joka sitten taas voi ilmetä jopa leikin, saivartelun ja myöhemmin myös uhon kautta. Ja ehkä nämä tavat kertoa ovat jopa luonnollisia valintoja suvussamme. Suvun verisestä lähihistoriasta kertomiseen on vaikuttanut myös kulunut aika: kertomusten kertomisen ja tapahtumien välillä on kulunut lähes 30 vuotta aikaa, joten kokemuksista osataan ja halutaan nyt kertoa, varsinkin tappoa tutkivalle suvun jäsenelle (vrt. Latvala 2001, 10; Vuorinen 2001, 129-130). Ja aika on vaikuttanut suvun sisäisiin lojaliteetteihin. Tapon aiheuttamat keskinäiset skismat on saatu korjattua, ja tähän juuri tapahtuneen käsittely ja siitä kertominen ovat osaltaan vaikuttaneet. Kukin suvun jäsen kertoo kuitenkin omalla tavallaan omine käsityksineen tapahtumasta. Esimerkiksi Saaralla on kaiken kattava näkemys tapahtuneeseen johtaneista syistä:

Yksi sellaanen, jotta mun äiti luuli sitä tätiäkin (Femmi), jotta se oli varmahan sillälailla, sil oli sellaasia hulluja, että varmahan oli (Veikeko) sittes sitä hulluutta periny, jotta tuo on, tuo on kolomantehen ja neljäntehen polveen se periytyy. (Saara 2001.)

\section{LOPUKSI}

Mitä siis muistellaan tämän poikkeuksellisen kuoleman, tapon kautta? Poikkeuksellisten kuolemien kategorian esittelyllä on tässä katsauksessa ollut tarkoitusperänsä: kyseessä on teemanumero kuolemasta ja tarkoituksena olikin osaksi käsitellä, miten tämä kuolema suhteutuu poikkeuksellisten kuolemien kategoriaan. Mutta kuten aineistoa tulkitessa huomataan, eivät kertojat erityisemmin muistele Veikon ja Väinön kuolemia niihin liittyvien rituaalien kautta. Sen sijaan kertojat nostavat esiin niitä merkityksiä, joita suku ja paikallisyhteisö ovat tapahtumalle antaneet: muistellaan ennemminkin veljeksien ominaisuuksia, sukulaisten ja kyläläisten mielipiteitä taposta sekä suvun selviytymistä tapahtumasta. Tämä tarkastelu on avannut myös näkökulmia tutkijan oman kulttuurin tutkimukseen ja sen synnyttämiin ongelmiin. Oman suvun ja varsinkin tämänkaltaisen hurjan tapahtuman tutkimisen yhdistämisessä ilmenikin yllättävän paljon hankaluuksia - hankaluuksia, jotka valitettavan onneksi syntyivät omassa päässäni. Olen elämäni aikana useasti kuullut tästä tapahtumasta, siihen johtaneista syistä ja suvun eri jäsenten reaktioista. Ja yleensä tämän tapauksen kerronta on johdattanut myös muutamien muiden tappeluja puukotusmuistojen ääreen. Minulle Veikko, Väinö ja tappo ovatkin pitkälti kertomusten synnyttämää mielikuvaa. Liittämällä tapahtunut tappo muihin vastaaviin sattumuksiin saakin se tavallaan selkeämmän ymmärryksen, osansa suvun historiallisesta jatkumosta. Ja tästä innostuksesta lähti myös kiinnostukseni tätä tarkastelemaani tappoa kohtaan. 
Mutta yksittäistapahtumana tarkasteltuna koen tapahtuneen itse nyt vielä liian hankalana ja läheisenä, niin ajallisesti kuin ihmissuhteidenkin kannalta katsottuna: muistojen Veikko on näet haastateltavilleni yhä olemassa. Koen muistelevat naiset surusta selviytymiskertomuksineen yllättävinä. Tämä on ollut kaikista ennakkotiedoistani ja -käsityksistäni huolimatta poikkeavaa. Ja toisaalta taas tämä on tuonut esiin muistitiedon merkittävyyden. Saadessaan mahdollisuuden rauhassa ja perin pohjin käsitellä tapahtunutta ovat kertojat tuottaneetkin toisenlaisia, syvemmällä vaikuttavia merkityksiä. Olen siis tavallaan kerrankin joutunut kohtaamaan muiden suvun jäsenten muistot ja suhteuttamaan niitä omiin muistoihini. Nämä omat muistoni ovat kuitenkin pääosin syntyneet isoisäni ja isäni sekä hänen veljiensä kertomusten kautta, ja niissä paino on ollut paitsi itse teon kuvailussa myös veljesten muiden "urotöiden" kuvailuissa. Kuulemani ja omaksumani kertomukset ovat siis noudattaneet lähinnä perinteisiä pohjalaisia puukkojunkkaritarinoiden piirteitä. Veikko onkin ilmentynyt minulle kertomusten kautta täydellisessä pohjalaisessa sotisovassa, ja toki minut on kolmannen polven edustajana ollut helppo vakuuttaa juuri näillä piirteillä. Tältä pohjalta mielenkiintoista olisikin tarkastella sitä, miten miesten muistot Veikosta ja Väinöstä eroavat tulkitsemistani naisten muistoista - tai omistani.

Tutkijana käsitykseni menneestä on kuitenkin muuttunut haastattelukertomusten myötä. Yhtenä ongelmana olenkin kokenut muun muassa vaikeuden tulkita syntyneitä ristiriitatilanteita; tilanteita joissa minun tulee päättää, otanko tämänkin asian tarkasteltavakseni. Tämä ongelma liittyy läheisesti kysymykseen siitä, minkälaista totuutta minulta tutkijana odotetaan. Onko minulla siis oikeutta tulkinnoissani painottaa jotakin näkemystä toisten kustannuksella? Tutkimuksen huono puoli onkin, ettei ristiriitatilanteita voi selvittää tai kiertää esimerkiksi fiktion keinoin. Varsinaisen Golgatan tieni olen siis kulkenut ja perkeleet ovat päässäni narisseet. Joten, tämä jääköön tästä taposta tähän.

\section{VIITTEET}

1. Käytän tässä yhteydessä adjektiivia epätavallinen tarkoittamaan tapahtuman poikkeuksellista ja harvinaista lopputulossa eli kuolemaa. Käsiteltävänä olevan sukuni haaran jälkeläiset ovat kohdanneet useampia puukotustapauksia, jotka eivät kuitenkaan ole johtaneet kuolemaan. Esimerkiksi lähisuvustani isoisäni (veljesten veli) tuomittiin 1940-luvun lopulla puukolla tapahtuneesta törkeästä pahoinpitelystä vankeuteen. Samoin setäni koki puukon voiman 1970-luvulla, ja tästä tapahtumasta myös minulla on muistoni. Toinen setäni oli sekä 1980-luvulla että 2000-luvulla mukana puukotusjupakoissa. Tässä kontekstissa velisurmasta kuultu on toki liikuttanut, mutta ennemminkin olen kokenut sen osaksi suvun historiallista jatkumoa. Tapahtunut ja siitä kertominen ovat antaneet minulle vastuuta oman sukuni tutkijana. 


\section{RiInA HaANPäÄ}

2. Tutkimuseettisiä ongelmia aiheuttaa muun muassa haastateltavien sekä kerronnan kohteena olevien ihmisten henkilökohtaisten tietojen käyttö tutkimuksessa. Vuonna 1999 voimaan tulleessa henkilötietolaissa määritellään, että henkilötietoja sisältävää tutkimusaineistoa saa käyttää vain siihen tarkoitukseen, johon suostumus haastateltavilta on saatu. Monet perinteentutkijat suosittavat tutkimuslupien lisäksi silti tutkimuksissa nimenomaan kertojien peitenimien käyttöä (Ukkonen 2000, 241). Itse esittelen haastateltavani käyttämällä heistä peitenimiä, mutta tekstissä tuon esiin kuitenkin heidän sukulaissuhteensa veljeksiin. Tämä siksi, että sukulaisuuden asteen noteeraus ja sen vaikutus ovat olennainen osa myös tarkastelussani esiin tulevia päätelmiä. Toisaalta taas historiatutkimuksissa historian toimijat esitellään yleensä oikeilla nimillä, ja osa Oral History -tutkimusta tekevistä tutkijoista esittelee myös kertojat käyttäen heidän oikeita nimiään. Alessandro Portelli (1997; 2002) saattaa artikkeleissaan kertojien nimet lukijan tietoisuuteen, ja hän myös pitää muistelijoita kanssatekijöinään. Tutkittavien asioiden onkin ehkä katsottu olleen siinä mielessä uniikkeja, että ne kuuluvat yksilöille ja siksi vaativat esittelyä oikeilla nimillä. Kotimaiset muistitietotutkijat ovat kuitenkin lähes poikkeuksetta käyttäneet tutkimuksissaan kertojien peitenimiä. Esimerkiksi Peltonen (1996; 2003) ja Fingerroos $(2004,392)$ eivät mainitse muistelijoita nimiltä. Kerronnan kohteena olevat Veikko ja Väinö on tarkastelussani esitelty heidän oikeita etunimiään käyttäen. Olen päätynyt tähän ratkaisuun lähinnä siksi, että tapahtumaa koskevat asiakirjat ovat avoimesti saatavilla. Samoin tapahtumasta on kirjoitettu julkisesti lehdissä (Kaubajoen Kunnallislehdessä oli 21.8.1974 etusivulla otsikoitu juttu Mies menetti henkensä punk.kotappelussa, ja myöhemmin samaisessa lehdessä oli 25.9.1974 juttu Veljestappo käräjillä). Myös minä itse tutkijana olen ollut monin tavoin julkisuudessa tapahtuman kanssa ja ansiosta.

3. Viranomaislähdemateriaalia on tapahtuman tiimoilta kertynyt runsaasti, sillä juttu eteni aina Korkeimpaan oikeuteen asti Veikon valitettua saamastaan tuomiosta. Poliisitutkintopöytäkirjoja todistajanlausuntoineen, kihlakunnanoikeuden ja hovioikeuden päätöksiä sekä Korkeimman Oikeuden päätöstaltiointeja on yhteensä yli 200 sivua.

4. Mielenkiintoista pohdinnan aihetta tarjoaa sanomalehden juttu Sukuseuran hallitus sai sakot salatun lapsen paljastamisesta (Helsingin Sanomat 31.12.2004). Nostetun syytteen käsittelyssä vedettiin rajaa siihen, pitääkö sukuseuran kirjaan soveltaa henkilötietolain pykälää, jonka mukaan suvun jäsenellä on oikeus kieltää omien tietojensa kerääminen ja tallentaminen. Ratkaisussa päädyttiin tulkintaan, jonka mukaan sukukirja on itsenäinen kirjallinen tuote, joka sisältää muutakin kuin puhtaita sukututkimuksellisia tietoja ( $\mathrm{mm}$. aikalaiskuvauksia, muistelmia ihmisten elämästä, historian kulusta poimittuja faktoja) ja siksi tuomiota varsinaisesta henkilörekisteririkoksesta ei tullut. Mielestäni pääosassa asian käsittelyssä on kuitenkin perhe ja suku sekä niiden tietojen jakamisen julkisuus. Miten julkisuuteen esitetyn valikointi tapahtuu? Miten vapaaehtoista sukuseuran kirjaan joutuminen on? Ja ylipäätään henkilökohtaisuuden asteen määrittäminen, sillä sen tiedon jakaminen ei ole yleistä eikä julkista. Henkilötietolaki velvoittaa tutkijaa huolehtimaan siitä, ettei hän käytä väärin ihmisten henkilötietoja tai arkaluontoisia asioita. Henkilö- 
tietolaki kuitenkin selkeyttää tilannetta silloin, kun tutkimuksen päämääränä on julkaiseminen, siis sukukirja tai sukuselvitys. Yksinomaan henkilökohtaisiin tai niihin verrattaviin tavanomaisiin tarkoituksiin ei henkilötietolakia voida soveltaa. Ratkaisuksi eettisten kysymysten pohtimiseen tarjotaankin usein neuvottelua ja yhteydenpitoa tutkittavien kanssa ja näiltä asian käsittelyyn luvan saamista (Ukkonen 2002, 4).

\section{TutKIMUSAINEISTOT}

\section{Haastattelut:}

— Leea s. 1962, haastateltu 9.7.2001.

- Saara s. 1922, haastateltu 3.8.2001.

— Ruut s. 1917, haastateltu 2.8.2001.

\section{Arkistolähteet:}

— Kauhajoen nimismiespiiri, pidätettyjen kirja, Vaasan maakunta-arkisto.

— Korkein Oikeus nro 1105/559, V.D.1975, päätöstaltiointi tekijän hallussa.

\section{Sanomalehdet, kirjeet:}

- Helsingin Sanomat 31.12.2004.

— Kaubajoen Kunnallislehti 21.8.1974; 28.8.1974; 4.9.1974; 25.9.1974

— Veikon kirje isoisälleni Vaasan Lääninvankilasta 3.3.1975. Kirje tekijän hallussa.

\section{KiRJALLisUUS}

ANTTONEN, VEIKKO 1999: Elämän kääntöpuolen etnografiaa: kuolema eri uskonnoissa ja kulttuuriperinteessä. - Kuparinen, Eero (toim.), Kun aika loppuu. Kuolema historiassa. Turku: Turun yliopiston historian laitos.

BRONFEN, ELISABETH \& GOODWIN, SARAH WEBSTER 1993: Introduction. - Death and Representation. Baltimore: The John Hopkins University Press.

DAVIS, NATALIE ZEMON 2001: Martin Guerren paluu. Helsinki: Gaudeamus. FINGERROOS, OUTI 2004: Haudatut muistot. Rituaalisen kuoleman merkitykset Kannaksen muistitiedossa. Suomalaisen Kirjallisuuden Seuran Toimituksia 985. Helsinki: Suomalaisen Kirjallisuuden Seura.

GINZBURG, CARLO 1996: Jobtolankoja. Kirjoituksia mikerobistoriasta ja historiallisesta metodista. Helsinki: Gaudeamus.

HEIMO, ANNE 2000: Kansallisesta murhenäytelmästä paikallishistoriaksi sammattilaisten muistoja vuodesta 1918. - Heimo, Anne \& Laukkanen, Anu \& Ukkonen, Taina (toim.), Teemanumero: Muistelu ja muistitieto. Elore 7(2) [online]. < http://cc.joensuu.fi/ loristi/2_00/hei200html> [21.2.2005.] 


\section{RiInA HaANPÄÄ}

KALELA, JORMA 1999: The Challenge of Oral History - The Need to Rethink Source Criticism. - Ollila, Anne (ed.), Historical Perspectives on Memory. Studia Historica 61. Helsinki: Suomalaisen Kirjallisuuden Seura.

— 2000: Historiantutkimus ja historia. Helsinki: Gaudeamus.

KOSKIVIRTA, ANU 2001: "Sisä̈nen vihollinen”. Henkirikos ja kontrolli Pohjois-Savossa ja Karjalassa Ruotsin vallan ajan viimeisinä vuosikymmeninä. [online]. < http:// ethesis.helsinki.fi/julkaisut/hum/histo/vk/koskivirta/sisainen.pdf $>$ [21.2.2005.] KNUUTTILA, SEPPO 1994: Tyhmän kansan teoria. Näkökulmia menneestä tulevaan. Tietolipas 129. Helsinki: Suomalaisen Kirjallisuuden Seura.

LATVALA, PAULIINA (toim.) 2001: Suvun suuri kertomus. Muistitietoa itsenäisen Suomen vaibeista. Kansanelämän kuvauksia 53. Helsinki: Suomalaisen Kirjallisuuden Seura.

— 2000: Mikä määrittää suvun muistitiedosta kertomista? - Heimo, Anne \& Laukkanen, Anu \& Ukkonen, Taina (toim.), Teemanumero: Muistelu ja muistitieto. Elore 7(2) [online]. < http://cc.joensuu.fi/ loristi/2_00/lat200html> [21.2.2005.]

NYGÅRD, TOIVO 2001: Erään tapon tarina. Romanien ja talonväen yhteenotto Alajärvellä 1888. Jyväskylä: Atena kustannus Oy.

PELTONEN, ULLA-MAIJA 1996: Punakapinan muistot. Tutkimus työväen muistelukerronnan muotoutumisesta vuoden 1918 jälkeen. Suomalaisen Kirjallisuuden Seuran Toimituksia 657. Helsinki: Suomalaisen Kirjallisuuden Seura.

- 2003: Muistin paikat. Vuoden 1918 sisällissodan muistamisesta ja unohtamisesta. Suomalaisen Kirjallisuuden Seuran Toimituksia 894. Helsinki: Suomalaisen Kirjallisuuden Seura.

PENTIKÄINEN, JUHA 1990: Suomalaisen lähtö. Kirjoituksia pohjoisesta kuolemankulttuurista. Suomalaisen Kirjallisuuden Seuran Toimituksia 530. Helsinki: Suomalaisen Kirjallisuuden Seura.

POHJOLA-VILKUNA, Kirsi 1995: Lapsen murha - Avaamaton tarina. - RoikoJokela, Heikki \& Pitkänen, Timo (toim.), Sisä-Suomen tuomiokirjat tutkimusläbteinäja elämän kuvaajina. Jyväskylä: Jyväskylän historiallinen yhdistys.

PORTELLI, ALESSANDRO 2002: What Makes Oral History Different? - Perks, Robert \& Thomson, Alistair (eds.), The Oral History Reader. London: Routledge.

- 1997: The Battle of Valle Giulia. Oral History and the Art of Dialogue. Madison, Wisconsin: The University of Wisconsin Press.

- 1991: The Death of Luigi Trastulli and Other Stories. Form and Meaning of Oral History. New York: State University of New York Press.

PÄLSI, SAKARI 1955: Punkko. Helsinki: Otava.

RAJALA, JUHA 2004: Kurittajia ja punkekosankareita. Väkivalta ja sen kontrolli Kannaksen rajaseudulla 1885-1917. Bibliotheca Historica 87. Helsinki: Suomalaisen Kirjallisuuden Seura.

RUOTSALA, HELENA 1998: Mie kotona kentällä ja kentällä kotona. - Mäkikalli, Maija \& Oinonen, Paavo (toim.), Integraatio, identiteetti, etnisyys. Tarkastelukulmia kulttuuriseen vuorovaikutukseen. Turun Yliopisto: Kulttuurisen vuorovaikutuksen ja integraation tutkijakoulun julkaisuja. 


\section{VELISURMASTA SUVUN MUISTOKSI}

SIIKALA, ANNA-LEENA 1984: Tarina ja tulkinta. Tutkimus kansankertojista. Suomalaisen kirjallisuuden Seuran Toimituksia 404. Helsinki: Suomalaisen Kirjallisuuden Seura.

SILTALA, JUHA 1994: Miehen kunnia. Modernin miehen taistelu häpeää vastaan. Helsinki: Otava.

SIPILÄ, JUHANI 2002: Maa luja, taivas korkia. Antti Tuurin Pobjanmaa-sarja. Helsinki: Otava.

SUOJANEN, PÄIVIKKI 1997: Työkaluna tutkijan persoona. - Viljanen, Anna Maria \& Lahti, Minna (toim.), Kaukaa haettua. Kirjoituksia antropologisesta kenttätyöstä. Helsinki: Suomen antropologinen seura.

UKKONEN, TAINA 2000: Menneisyyden tulkinta kertomalla. Muistelupube oman historian ja kokemuskertomusten tuottamisprosessina. Suomalaisen kirjallisuuden Seuran Toimituksia 797. Helsinki: Suomalaisen Kirjallisuuden Seura.

— 2002: Mietteitä muistitietohistorian eettisistä ja lähdekriittisistä ongelmista. Elore 9(2) [online]. <http://cc.joensuu.fi/ loristi/2_02/ukk202html> [26.2.2005.] VILKUNA, KUSTAA 1949: Puukkojunkkarit, rahahäät ja heränneet. - Kotiseutu 1949(13): 131-135.

— 1969: Etelä-Pohjanmaan omaleimaisuus. - Kansantaide ja perinnepolitiikeka. Kansantaiteen seminaari Seinäjoella 10.6.-15.6.1968. Suomen Kulttuurirahasto.

VIRRANKOSKI, PENTTI 1965: Härmän häjyt ja Kauhavan komiat. - Kotiseutu 1965(29): 182-190.

VUORINEN, PIHLA 2001: Perhekertomukset nuorten aikuisten identiteetin rakennusaineksina. - Kupiainen, Tarja \& Laitinen, Katja \& Vakimo, Sinikka (toim.), Minä? Missä? Milloin? Kolmetoista tulkintaa identiteeteistä. Helsinki: Suomalaisen Kirjallisuuden Seura.

- 2002: Doing Research Among Family and Friends. Problems and Advantages. - Lives, Histories and Identities. Studies on Oral Histories, Life- and Family Stories. Vol. 3. Tartu: University of Tartu.

YLIKANGAS, HEIKKI 1974: Härmän häjytja Kaubavan herra. Kuvaus puukeojunkkareitten ja virkavallan välisestä ybteenotosta 1860-luvun lopulla. Helsinki: Otava.

-1976: Punkkejunkekareitten esiinmarssi. Väkivaltarikollisuus Etelä-Pohjanmaalla 17901825. Helsinki: Otava.

\section{Riina Haanpää (FM) on juuriltaan pohjalainen Turun yliopiston folkloristi.}

